\title{
The genus Lachnagrostis (Gramineae) in Australia
}

\author{
S.W.L. Jacobs
}

\begin{abstract}
Jacobs, S.W.L. (Royal Botanic Gardens, Sydney, NSW 2000, Australia) 2001 The genus Lachnagrostis (Gramineae) in Australia. Telopea 9(3): 439-448. Lemma epidermal features were examined in species of Agrostis, Deyeuxia and Calamagrostis. As a result the genus Lachnagrostis is recognised and new combinations provided for L. adamsonii, L. aequata, L. collicola, L. drummondiana, L. lacunis, L. limitanea, L. meionectes, L. punicea and L. robusta. A key distinguishing Lachnagrostis from the related genera Dichelachne, Deyeuxia, Agrostis is given, along with a characterisation of the four genera. Synonymy is provided for the other species of Lachnagrostis recognised in Australia. It is concluded that both Deyeuxia and Calamagrostis are diverse and highly variable and little is to be gained by combining them at this stage though their current circumscriptions are probably suboptimal.
\end{abstract}

\section{Introduction}

Agrostis, Calamagrostis, Lachnagrostis and Deyeuxia have been treated variously by different authors, though they are all regarded as closely related in either the tribe Agrosteae, tribe Aveneae or subtribe Agrostidineae (Soreng and Davis 2000). Edgar and Forde (1991) and Edgar (1995) summarise these different treatments and decided to recognise all four genera, with Calamagrostis not recorded from Australasia.

Epidermal features of the florets have been used before to unravel relationships in the grasses (Jacobs and Lapinpuro 1986; Dogan 1988; Barkworth 1990). Such characters are of particular use in groups where floret characters are conservative, as here. A study of lemma and glume epidermal features was started in an attempt to solve the confusion surrounding the limits of these genera, at least for New South Wales. While the project is far from finished, some results are already clear.

Lachnagrostis is already recognised in New Zealand (Edgar 1995; Edgar and Connor 2000), and several of the species are shared between Australia and New Zealand. It is desirable that the same names are used for these species throughout their range.

As a preliminary to a new edition of Wheeler et al. (1990) this paper presents evidence in support of Edgar's (1995) and Edgar and Connor's (2000) recognition of Lachnagrostis, and makes the necessary new combinations for the remaining Australian species to allow uniform treatments.

\section{Methods}

All Australian species of Agrostis s. lat. and Deyeuxia were examined, with several replicates of most. The number of replicates reflected the number of specimens held at NSW and their geographic range.The number of replicates varied from $0-16$, the latter for both L. filiformis [A. avenacea] and D. quadriseta. All of the species of non-Australian Agrostis, Deyeuxia and Calamagrostis represented in the collections at NSW were 
examined in this first stage of the project. The total number of specimens examined was 425 , representing c. 240 taxa.

Glumes and florets were removed from voucher samples, mounted on stubs and coated with gold using a sputter coater. The specimens were then examined using a Scanning Electron Microscope, and a record kept on film. Characters observed included the pattern of long and short cells of the epidermis, distribution of silica cells, distribution of prickles, pattern and prominence of cell walls, development of the rachilla extension, distribution of macrohairs, and the awn base.

\section{Results and Discussion}

The characters observed on the glumes were reasonably uniform and do not appear, at this stage, to offer much taxonomic information. The lemma surface, however, was informative.

\section{Agrostis/Lachnagrostis}

The species formerly included in Agrostis in Australia have three distinct lemma epidermal patterns:

(i) the so-called Trichodium net pattern (Björkman 1960; Edgar and Forde 1991) (Fig. 1a);

(ii) raised margins of epidermal cells, with or without prickles (Fig. 1b) a pattern more common amongst grasses; and

(iii) a comparatively smooth epidermis, the cell walls appearing more or less wavy in outline but the margins flush with the surface, prickles present or absent and macrohairs present or absent (Fig. 1c).

All Australian native species, some introduced species and several non-Australian species here included in Agrostis s. str., have epidermis type (i). Some species of Agrostis introduced into Australia, and several non-Australian species have epidermis type (ii); these species are also here included in Agrostis s. str. There is still discussion as to which is the type species of Agrostis; at least one contender has a type (i) epidermis and another has a type (ii).

The species that have a type (iii) epidermis include the type species of Lachnagrostis, L. filiformis [Agrostis avenacea]. These species were formerely all included in Agrostis in Australasia. The species are also characterised by having:

(i) a palea almost as long as the lemma (always > 50\%);

(ii) an obvious and well-developed hairy rachilla extension that, with the apical hairs, may be almost as long as the lemma; and

(iii) a tendency for the whole inflorescence to become detached and act as the diaspore, though this character is not always obvious and apppears to be suppressed in some species.

On the basis of the epidermal features and the other more or less correlated characters, recognition of the genus Lachnagrostis is supported.

\section{Deyeuxia}

The lemma epidermal patterns in Deyeuxia are more varied and less discrete than in Agrostis. There is a pattern that is almost reminiscent of the Trichodium net in one sample (Fig. 1d), but this is not constant in that species (Fig. 2a). Generally the patterns 
are reminiscent of the type (ii) epidermis above (Figs 1d, 2a-d, 3a), but considerably more variable, not as discrete, and with more variation within taxa than evident with any of the taxa in Agrostis s. lat. (e.g. Figs 1d, 2a). From the lemma epidermal patterns there is a suggestion that there would be some value in reassessing species, and this would be necessary before any attempt was made to split the genus. On the basis of the epidermal patterns there appears some justification in retaining Deyeuxia as it is until a more detailed reassessment is completed.

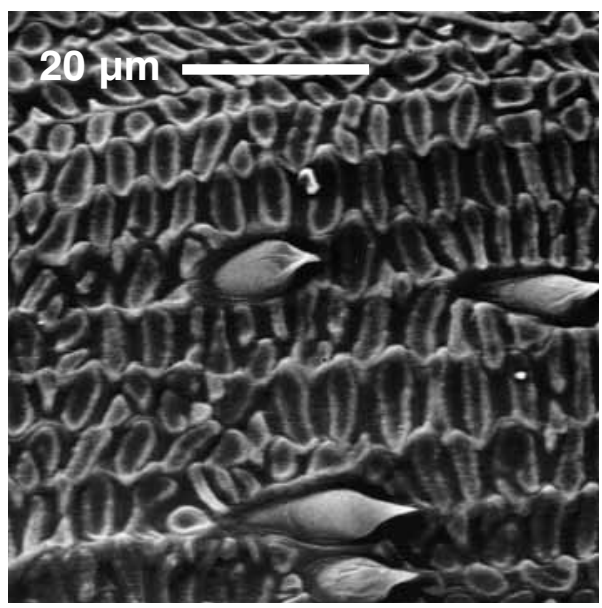

a

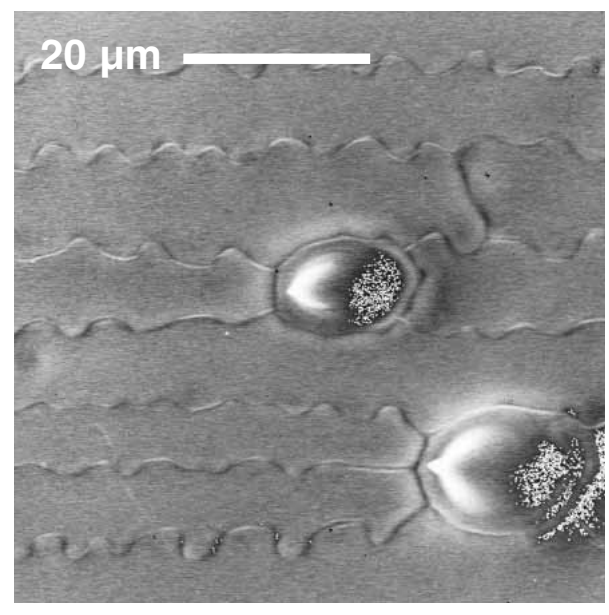

C

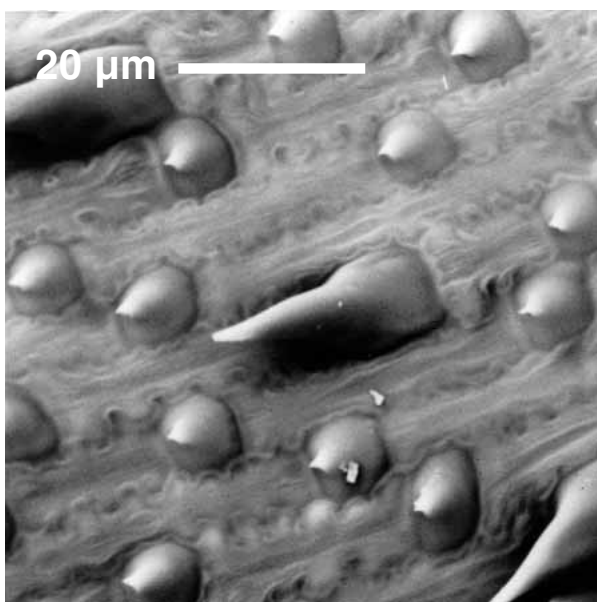

b

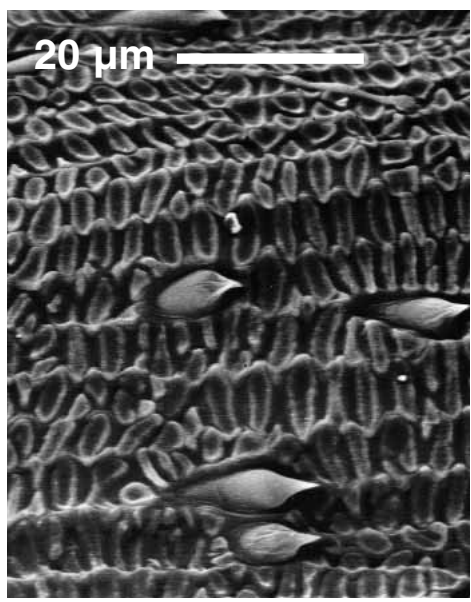

d

Fig.1. a, Agrostis muelleriana lemma epidermis with a typical Trichodium net pattern of silica plates (type i). b, Agrostis spica-venta lemma epidermis showing long-cells with raised wavy margins, short prickles arising from short-cells (type ii) and a few longer prickles. The longer white bar represents $10 \mu \mathrm{m}$. c, Lachnagrostis billardieri lemma epidermis with almost flat wavy margins of the long-cells and short-cells, with some short-cells bearing prickles (type iii). d, Lemma epidermis of Deyeuxia parviseta var. parviseta with a Trichodium net-like pattern. See also another specimen of the same species but a different variety with an apparently different epidermal pattern in Fig. 2a. 


\section{Calamagrostis}

The commonest lemma epidermal pattern in Calamagrostis is type (ii) (Fig. 3b) but the variation is large (Figs $3 b-d$ ), and clearly the genus contains a mixture of several taxa. Some of the variation in character states at least appears different to that in Deyeuxia (e.g. Fig. 3d). There is obviously much work required in sorting out Calamagrostis and there appears little justification at this stage to compound the confusion by incorporating Deyeuxia into Calamagrostis. Some of the lemma epidermal patterns in Calamagrostis are indeed similar to some of those in Deyeuxia, but whether the best

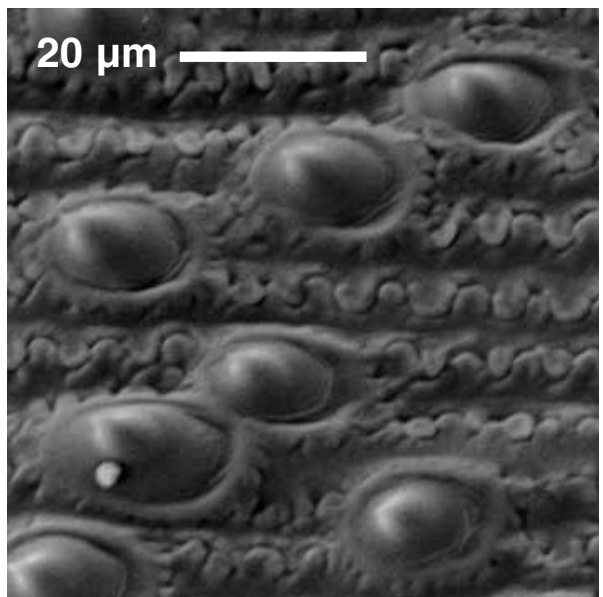

a

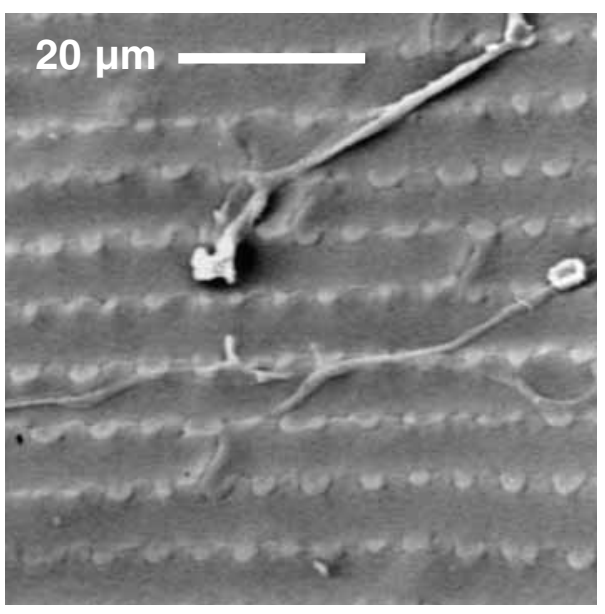

C

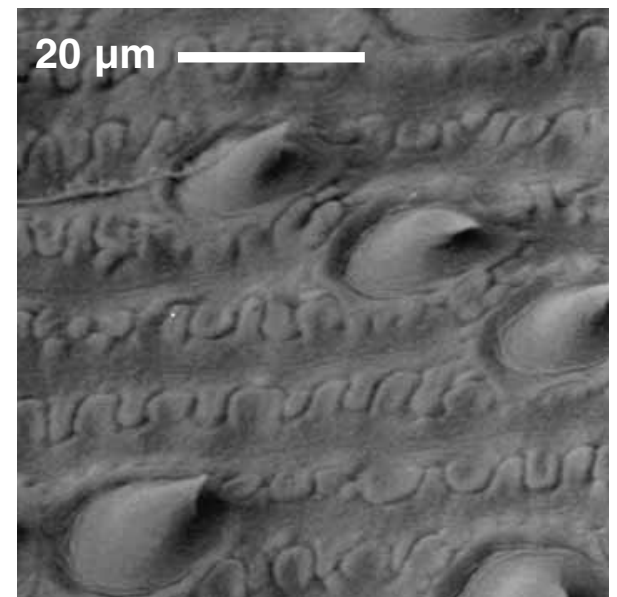

b

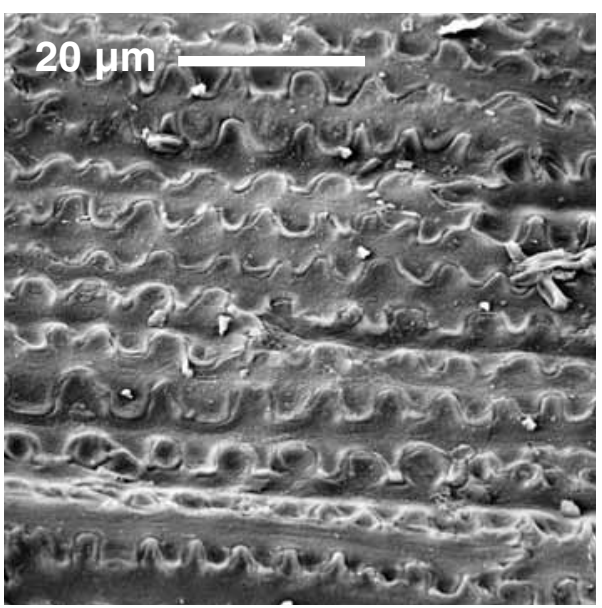

d

Fig. 2. a, Lemma epidermis of Deyeuxia parviseta var. boormanii with a variant of a type (ii) pattern where the long-cell walls have wavy raised margins (see also Fig. 3d). b, Lemma epidermis of Deyeuxia decipiens with a variant of the type (ii) pattern of raised wavy long-cell margins. c, Lemma epidermis of Deyeuxia scaberula with a variant of the type (ii) pattern of raised wavy long-cell margins. d, Lemma epidermis of Deyeuxia inominata with a variant of the type (ii) pattern showing the raised and wavy margins of the long-cells. This variant has very few short-cells or prickles. 
option is to include those species in Deyeuxia or to include Deyeuxia in Calamagrostis remains to be seen. The type species of Calamagrostis is C. epigeios (L.) Roth (Fig. 3b), which has an epidermis similar to type (ii), a type also common in Deyeuxia.

\section{Key to some related genera}

1 Lemma chartaceous to hardened, more or less stiff at maturity, often scaberulous or scabrid, especially above ........................................................................................................ 2

$1 *$ Lemma membranous to chartaceous, usually soft at maturity ...... 3

2 Awn arising subapically, $>6 \mathrm{~mm}$ long, frequently $>10 \mathrm{~mm}$ long; lemma apex entire or 2-toothed Dichelachne

$2^{*}$ Awn arising from various positions on the lemma but usually not $>6 \mathrm{~mm}$ long when apical or subapical; lemma apex entire or minutely 4 -toothed

Deyeuxia

3 Inflorescence axis persistent; rachilla extension present but $<20 \%$ lemma length, glabrous or shortly hairy; lemma epidermis with a well-developed raised pattern ........................ Agrostis

$3^{*}$ Inflorescence often detaching as a diaspore; rachilla extension usually well developed and often with hairs almost as long as the extension itself, 30-100\% lemma length; lemma epidermis with a discernible pattern of low relief Lachnagrostis

\section{Agrostis L.}

Tufted, rhizomatous, sometimes stoloniferous, often delicate annuals or perennials, to $1.2 \mathrm{~m}$ tall. Ligule membranous; blade rolled in bud, linear, flat, sometimes folded or involute, scabrous (at least the margins). Inflorescence usually a more or less contracted, usually much branched panicle of small spikelets. Spikelets often gaping, with 1 bisexual floret, on slender pedicels, disarticulating above or below the glumes, rachilla often produced as a hairy bristle. Glumes equal or subequal, acute or acuminate, keeled, 1-nerved, membranous, often shining, awnless, scabrous on the keel and back. Lemma usually shorter than the glumes, thin and soft, \pm hairy, 3-5nerved, awnless or dorsally awned, callus \pm hairy. Palea shorter than the lemma or absent.

A genus of c. 200 species, often growing in cold regions especially of the Northern Hemisphere.

\section{Dichelachne Endl.}

Tufted annuals or perennials. Ligule membranous; blade flat or convolute, usually scabrous, often pubescent. Inflorescence a dense spike-like or loose to open panicle. Spikelets solitary, pedicellate, narrow, numerous and overlapping on the short branches, disarticulating above the glumes; one bisexual floret, rachilla usually not produced as a bristle. Glumes similar, subequal, narrow, subulate, keeled on the single, scabrous nerve. Lemma shorter than the glumes, firm, entire or bifid, faintly nerved, awned from below the apex, the awn slender, curved or bent, column usually twisted; callus hairy. Palea narrow, slightly shorter than the lemma.

A genus of c. 9 species from Australasia.

\section{Deyeuxia P.Beauv.}

Erect, tufted perennials. Ligule membranous, entire or toothed; blade flat or convolute, mostly basal, tapering into a fine point, slightly rough on both surfaces. Inflorescence a terminal, contracted or \pm open panicle. Spikelets shortly pedicellate, laterally compressed, numerous and often densely overlapping, rachilla disarticulating between the glumes and the lemma, floret 1, bisexual, rachilla often produced as a bristle beyond the floret, rarely a second floret present. Glumes subequal, 1-nerved, 


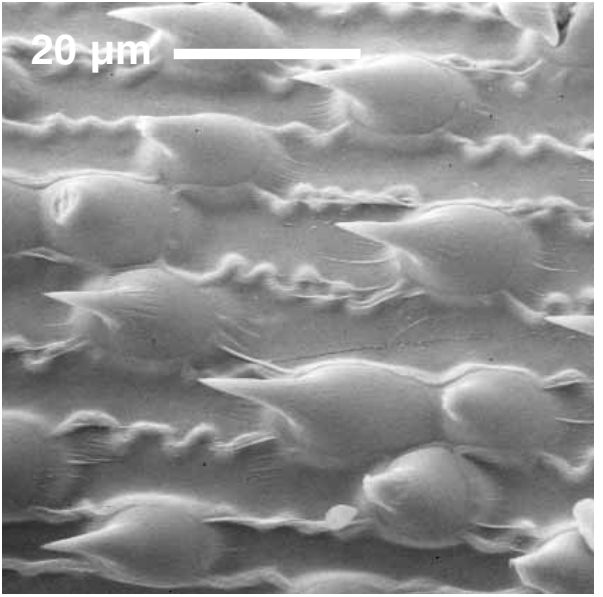

a

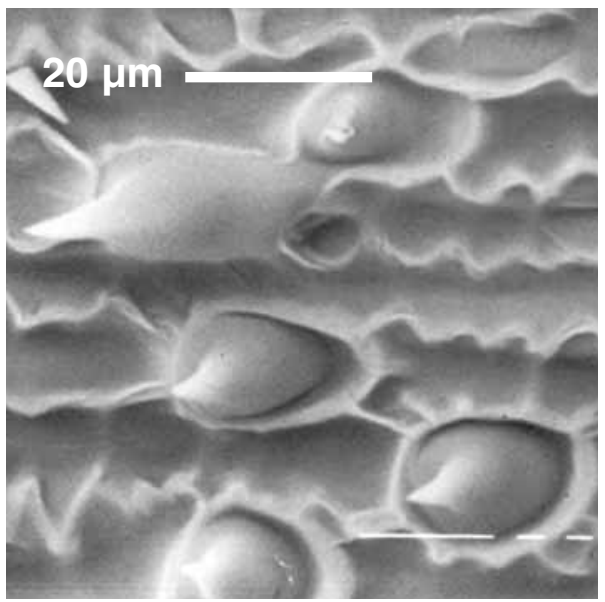

C

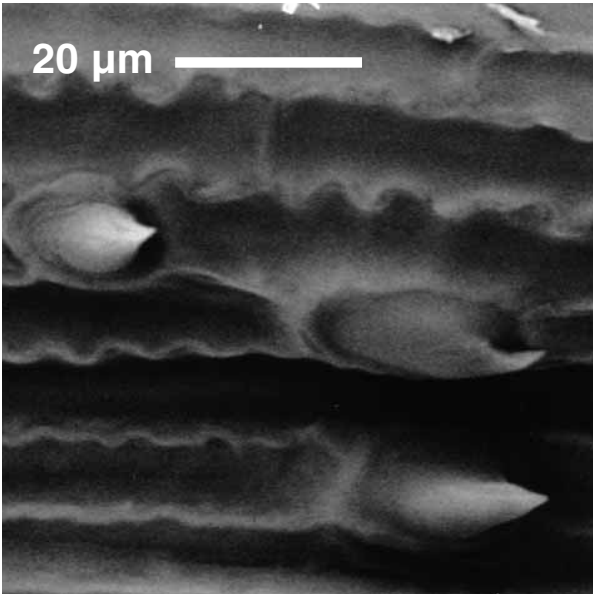

b

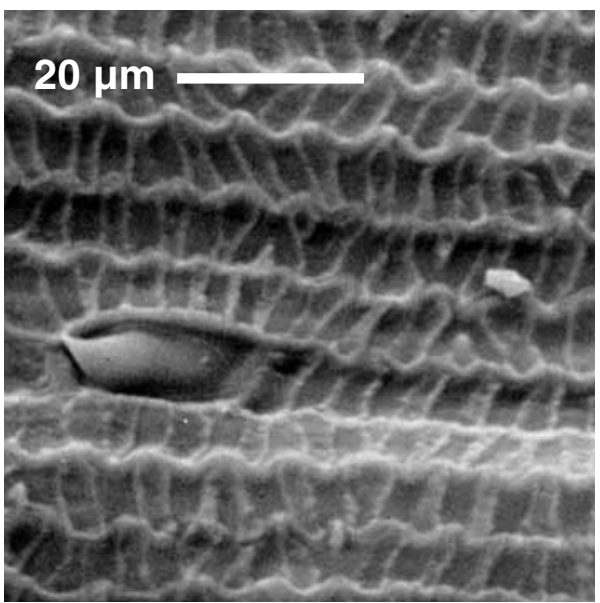

d

Fig. 3. a, Lemma epidermis of Deyeuxia quadriseta showing the type (ii) pattern: long-cell walls with raised and wavy margins and the long-cells interspersed with short-cells and these often bearing prickles. b, Lemma epidermis of Calamagrostis epigeos (type species of Calamagrostis) with the classical type (ii) pattern: long-cell walls with raised and wavy margins and the long-cells interspersed with short-cells and these often bearing prickles. The longest white bar represents $10 \mu \mathrm{m}$. c, Lemma epidermis of Calamagrostis scabra with a variant of the type (ii) pattern where the wavy margins of the long-cell walls produce secondary ridges that join the margins across the cells. The longest white bar represents $10 \mu \mathrm{m}$. $\mathbf{d}$, Lemma epidermis of Calamagrostis tenella with an almost Trichodium net-like (type i) pattern that may also be an extreme form of the pattern in Fig. 3c. The longest white bar represents $10 \mu \mathrm{m}$.

keeled, \pm firm, awnless, acute. Lemma almost as long as or longer than the glumes, 3-5-nerved, entire or toothed at the apex, firmer in texture than the glumes, with a short, often bent, dorsal awn or awnless, callus often hairy (hairs shorter than the lemma). Palea as long as the lemma, 2-nerved and 2-keeled, thinly membranous and soft.

A genus of c. 100 species of temperate regions of Australasia. 


\section{Lachnagrostis Trin.}

Tufted perennials or annuals. Ligule membranous; blade flat or folded with inrolled margins. Culms fragile at maturity; nodes glabrous. Inflorescence an open, muchbranched panicle, often completely detaching at maturity. Spikelets small, mostly 1-flowered, with the rachilla extending beyond the floret and minute to nearly as long as the spikelet; rachilla extension glabrous to long-hairy. Glumes more or less equal, as long as the spikelet, acute, firmer than the lemma, 1(-3)-nerved, keel scabrid. Lemma shorter and thinner than the glumes, usually hairy though sometimes glabrous, (3-)5nerved, dorsally-awned (rarely sub-apical or even more rarely absent); awn scabrid, geniculate or straight. Palea 50-100\% lemma length.

A genus of c. 20 species throughout temperate areas and habitats of Australasia.

Lachnagrostis adamsonii (J.W. Vickery) S.W.L. Jacobs, comb. nov.

Basionym: Agrostis adamsonii J.W. Vickery (107 :1941)

Type: Victoria: Melbourne, 12 Nov 1853 Adamson 226 (K).

Lachnagrostis aemula (R. Br.) Trinius (1820).

Basionym: Agrostis aemulea R. Brown (1810).

Type: New South Wales: Port Jackson and Port Dalrymple R. Brown 6219 pro parte (BM; lectotype, Vickery 1941).

Synonyms: Vilfa aemula (R. Br.) Beauvois (1812); Deyeuxia aemula (R. Br.) Kunth (1829); Calamagrostis aemula (R. Br.) Steudel (1840).

Agrostis semibarbata Trinius (1841).

Agrostis solandri F. Mueller (1864) pro parte.

Lachnagrostis aequata (Nees) S.W.L. Jacobs, comb. nov.

Basionym: Agrostis aequata Nees (412: 1843).

Type: Tasmania: 18 Jan 1838, Gunn 1005 (C).

Synonyms: Deyeuxia aequata (Nees) Benth. (1878); Calamagrostis aequata (Nees) J.M. Black (1922).

Lachnagrostis billardieri (R. Br.) Trinius (1820).

Basionym: Agrostis billardieri R. Brown (171: 1910).

Type: New South Wales: Port Jackson R. Brown 6218 (BM; lecto, Vickery 1941).

Synonyms: Vilfa billardieri (R. Br.) Beauvois (1812); Lachnagrostis billardieri (R. Br.)

Trinius (1820); Deyeuxia billardieri (R. Br.) Kunth (1829); Calamagrostis billardieri (R. Br.) Steudel (1840); Calamagrostis aemula var. billardieri (R. Br.) Maiden \& Betche (1916).

Avena filiformis Labillardiere (1804) non Forster (1786).

Agrostis labillardieri Roemer \& Schultes (1817).

Agrostis diffusa Banks \& Solander ex Hooker (1853) non Besser (1809) vel Host (1809).

Agrostis solandri F. Mueller (1864) pro parte.

Lachnagrostis billardieri subspecies tenuiseta (D. Morris) S.W.L. Jacobs, stat. et comb. nov. Basionym: Agrostis billardieri var. tenuiseta D. Morris (147: 1990).

Type: Tasmania: Dolphin Sands, Nine Mile Beach, 10 Dec 1984 Buchanan 4763 (HO).

Lachnagrostis collicola (D. Morris) S.W.L. Jacobs, comb. et stat. nov.

Basionym: Agrostis billardieri var. collicola D. Morris (147: 1990).

Type: Tasmania: Saddle between The Hippo and Moonlight Ridge Hill 3, 10 Feb 1985, Collier 309 (HO).

Agrostis collicola (D. Morris) A.J. Brown \& N.G. Walsh (2000).

Lachnagrostis drummondiana (Steud.) S.W.L. Jacobs, comb. nov.

Basionym: Dichelachne drummondiana Steudel (120: 1854).

Type: Western Australia: South-west Australia, Drummond 371 (K).

Synonyms: Deyeuxia drummondiana (Steud.) Bentham (1878); Agrostis drummondiana (Steud.) Vickery (1941). 
Lachnagrostis filiformis (Forst.) Trinius (1820).

Basionym: Avena filiformis G. Forster (1786).

Type: Cult. ex Nova Hollandia, Oct. 1818, Swartz ex Herb. J. Gay (K)

Synonyms: Agrostis filiformis (Forst.) Sprengel (1807), non Villars (1787); Calamagrostis filiformis (Forst.) Cockayne (1908); Deyeuxia filiformis (Forst.) Petrie in Chilton (1909), non (Griseb.) Hooker (1897).

Agrostis avenacea Gmelin (1791); Calamagrostis avenacea (Gmel.) Becherer (1938).

Agrostis retrofracta Willdenow (1809); Vilfa retrofracta (Willd.) Beauvois (1812); Lachnagrostis retrofracta (Willd.) Trinius (1820); Deyeuxia retrofracta (Willd.) Kunth (1829); Calamagrostis retrofracta (Willd.) Link ex Steudel (1840).

Agrostis debilis Poiret (1810); Vilfa debilis (Poir.) Beauvois (1812).

Agrostis forsteri Roemer \& Schultes (1817); Lachnagrostis forsteri (Roem. \& Schultes) Trinius (1824); Deyeuxia forsteri (Roem. \& Schultes) Kunth (1829); Calamagrostis forsteri (Roem. \& Schultes) Steudel (1840).

Lachnagrostis willdenowii Trinius (1824); Calamagrostis willdenowii (Trin.) Steudel (1854). Agrostis ligulata Steudel (1854).

Agrostis solandri F. Mueller (1864) pro parte.

Lachnagrostis lacunis (D. Morris) S.W.L. Jacobs, comb. nov.

Basionym: Agrostis lacunis D. Morris (149-153: 1990).

Type: Tasmania: Twisted Tarn, Mt Field National Park, 1110 m, 1 Mar 1983, A.M. Buchanan 1187 (HO93290).

Lachnagrostis limitanea (J.M. Black) S.W.L. Jacobs, comb. nov.

Basionym: Agrostis limitanea J.M. Black (137: 1931).

Type: South Australia: Near Riverton, March 1931, W.C. Johnston (AD).

Lachnagrostis meionectes (J. Vickery) S.W.L. Jacobs, comb. nov.

Basionym: Agrostis meionectes J. Vickery (12: 1966).

Type: New South Wales: Lake Cootapatamba, Kosciusko, L.A.S. Johnson and E.F. Constable NSW15995 (NSW).

Lachnagrostis plebeia (R. Br.) Trinius (1820).

Basionym: Agrostis plebeia R. Brown (1810).

Type: New South Wales: Port Jackson, R. Brown 6220 (BM); Vickery (1941) points out that this is the only specimen of this species not from Western Australia and suggests some confusion with collecting information.

Synonyms: Vilfa plebeia (R. Br.) Beauvois (1812); Deyeuxia plebeia (R. Br.) O. Kuntze (1898); Calamagrostis aemula var. plebeia Maiden \& Betche (1916).

Didymochaeta australis Steudel (1854); Deyeuxia australis (Steud.) Bentham and Hooker (1883).

Lachnagrostis preissii Nees in Lehmann (1846).

Type: Western Australia: In regionibus interioribus Australiae meridionaleoccidentalis, Oct. 1840, Preiss 1846 (K, BM).

Synonyms: Deyeuxia preissii Nees ex Index Kewensis (1893); Deyeuxia forsteri var. preissii (Nees) Bentham (1878); Agrostis preissii (Nees) Vickery (1941).

Agrostis solandri F. Mueller (1864) pro parte.

Lachnagrostis punicea (A.J. Brown \& N.G. Walsh) S.W.L. Jacobs, comb. nov.

Type: Tasmania: New Norfolk, 15 Nov 1840, Ballantine 1446 (K).

Based on: Agrostis billardieri var. setifolia Hooker (115: 1858).

Agrostis aemula var. setifolia (Hook. f.) Vickery (1941).

Lachnagrostis punicea subspecies filifolia (Vickery) S.W.L. Jacobs, comb. et stat. nov. Basionym: Agrostis billardieri var. filifolia Vickery (110: 1941).

Type: Victoria: Hawkesdale, Dec 1901, Williamson (K). 
Agrosts punicea var. filifolia (Vickery) A.J. Brown \& N.G. Walsh (2000).

Lachnagrostis robusta (Vickery) S.W.L. Jacobs, comb. nov.

Basionym: Agrostis billardieri var. robusta Vickery (110: 1941).

Type: Victoria: Melbourne, 27 Nov 1853, Adamson 224 (K).

Agrostis robusta (Vickery) A.J. Brown \& N.G. Walsh (2000).

Lachnagrostis rudis (Roem. \& Schult.) Trinius (128: 1820).

Basionym: Agrostis rudis Roem. \& Schult. (1817).

Type: without locality, R. Brown (BM).

Synonyms: Calamagrostis rudis (Roem. \& Schult.) Steudel (1854).

Agrostis scabra R. Brown (1810) non Willdenow (1797); Vilfa scabra (R. Br. ) Beauvois (1812); Deyeuxia scabra (R. Br.) Kunth (1829).

\section{Acknowledgments}

I thank Jane Dalby, Liz Norris and Kristina Frank who assisted with SEM or photography at different stages of the project.

\section{References}

Barkworth, M.E. (1990) Nassella (Gramineae, Stipeae): revised interpretation and nomenclatural changes. Taxon 31: 597-614.

Beauvois, P.de A.M.F.J. (1812) Essai d'une nouvelle Agrostographie.

Becherer (1938) Notice sur la nomenclature de quelques graminées. Candollea 7: 518-521.

Bentham, G. (1878) Flora of Australia. 7.

Bentham, G. and Hooker, J.D. (1883) Genera Plantarum. 3.

Besser, W.S.J.G. von (1809) Primitiae florae Galiceae austriaceae utriusque. 1.

Black, J.M. (1922) Flora of South Australia. 1. (Government Printer: Adelaide).

Black, J.M. (1931) Additions to the flora of South Australia 29. Transactions and Proceedings of the Royal Society of South Australia 55: 136-142.

Björkman, S.O. (1960) Studies in Agrostis and related genera. Symbolae Botanicae Upsaliense 17: $1-112$.

Brown, R. (1810) Prodromus florae Novae Hollandiae.

Brown, A.J. and Walsh, N.G. (2000) A revision of Agrostis billardieri R. Br. (Poaceae). Muelleria 14: 65-90.

Chilton, C. (1909) The subantarctic islands of New Zealand. 2.

Cockayne, L. (1908) Reports on botanical surveys [of districts of New Zealand]. Tongariro Nationalo Park. (New Zealand Government Printer: Wellington).

Dogan, M. (1988) A scanning electron microscope survey of the lemma in Phleum, Pseudophleum, and Rhizocephalus (Gramineae). Notes from the Royal Botanic Garden Edinburgh 45: 117-124.

Edgar, E. (1995) New Zealand species of Deyeuxia P. Beauv. and Lachnagrostis Trin. (Gramineae: Aveneae). New Zealand Journal of Botany 33: 1-33.

Edgar, E. and Connor, H.E. (2000) The grasses of New Zealand. (Manaaki Whenua Press: Lincoln)

Edgar, E. and Forde, M.B. (1991) Agrostis L. in New Zealand. New Zealand Journal of Botany 29: 139-161.

Forster, J.G. (1786) Florulae insularum Australium prodromus.

Gmelin, J.F. (1791) Systema vegetabilium. part 1.

Hooker, J.D. (1853) Flora Novae-Zelandiae. 1.

Hooker, J.D. Flora Tasmaniae. 2.

Hooker, J.D. (1897) [1896?] Flora of British India. 7.

Host, N.T. (1809) Icones et descriptiones graminum austriacorum. 4.

Index Kewensis (1893) p. 740.

Jacobs, S.W.L. \& Lapinpuro, L. (1986) The Australian species of Amphibromus. Telopea 2: 715-729.

Kunth, C.S. (1829) Révision des Graminées.

Kuntze, C.E.O. (1898) Revisio generum plantarum. III ii. 
Lehmann, J.G.C. (1846) Plantae Preissianae. 2.

Maiden, J.H. and Betche, E. (1916) Census of New South Wales Plants. (New South Wales Government Printer: Sydney)

Morris, D.I. (1990) New taxa and a new combination in Tasmanian Poaceae. Muelleria 7: 147-171.

Mueller, F.J.H. (1864) The Vegetation of the Chatham Islands.

Nees von Esenbeck, C.G.D. (1843) Gramineae Novae Hollandiae, presertim Insulae Van Dieman. Hooker's London Journal of Botany 2: 409-420.

Poiret, J.L.M. (1810) Encyclopédie methodique botanique Supplement 1.

Roemer, J.J. and Schultes, J.A. (1817) Systema vegetabilium 2.

Soreng, R.J. and Davis, J.I. (2000) Phylogenetic structure in Poaceae subfamily Pooideae as inferred from molecular and morphological characters: misclassification versus reticulation. pp 61-74 in S.W.L. Jacobs and J. Everett (eds) Grasses: systematics and evolution. (CSIRO: Melbourne)

Sprengel, K. (1807) Mantissa prima florae halensis.

Steudel, E.G. (1840) Nomenclator botanicus edn 2, vol.1.

Steudel, E.G. (1854) Synopsis plantarum glumacearum.

Trinius, C.B. (1820) Fundamenta agrostographie.

Trinius, C.B. (1824) De Graminibus unifloris et sesquifloris.

Trinius (1841) Agrostidea II, callo rotundo. Mémoires de l'Académie Impériales des Sciences de St.-Pétersbourg, Classe Physico-Mathématiques ser. 6: 6 (2) 247-390.

Vickery, J.W. (1941) A revision of the Australian species of Agrostis Linn. Contributions from the New South Wales National Herbarium 1: 101-119.

Vickery, J.W. (1966) A new species of Agrostis from the Australian Alps. Contributions from the New South Wales National Herbarium 4: 12-13.

Villars, D. (1787) Histoire des plantes de Dauphine 2.

Wheeler, D.J., Jacobs, S.W.L. \& Norton, B.E. (1990) Grasses of New South Wales. 2nd. edition. (University of New England Press: Armidale).

Willdenow, C.L. von (1797) Species Plantarum edn 1.

Willdenow, C.L. von (1809) Enumeratio Plantarum Horti Regii Berolinensis. 